\title{
Biostimulant alleviates abiotic stress of mango grown in semiarid environment
}

\author{
Marcelle A. da Silva ${ }^{1}$, Ítalo H. L. Cavalcante ${ }^{2}$, Laiane E. D. Mudo ${ }^{2}$, Vespasiano B. de Paiva Neto², \\ Renata A. e Amariz ${ }^{2}$ \& Jenilton G. da Cunha ${ }^{2}$ \\ ${ }^{1}$ Universidade Federal do Vale do São Francisco/Departamento de Ciências Biológicas, Petrolina, PE, Brasil. E-mail: marcelle.almeida@univasf.edu.br - \\ ORCID: 0000-0002-9422-4077 \\ ${ }^{2}$ Universidade Federal do Vale do São Francisco/Departamento de Engenharia Agronômica, Petrolina, PE, Brasil. E-mail: italo.cavalcante@univasf.edu.br \\ (Corresponding author) - ORCID: 0000-0003-1610-1546; laiane.eugenia@hotmail.com - ORCID: 0000-0002-3721-0592; vespasiano.paiva@univasf.edu.br - \\ ORCID: 0000-0003-3347-7043; renataamariz@hotmail.com - ORCID: 0000-0002-9581-3594; jeniltongomes@hotmail.com - ORCID: 0000-0003-4110-6605
}

\begin{abstract}
The shoot maturation phase is important for growing mango tree because it precedes the floral induction, when plants are under stress caused by high temperatures and low water availability, that could be reduced by using plant biostimulant. Thus, the current study aimed to use a plant biostimulant containing yeast extract and amino acids to alleviate abiotic stress in mango plants, cv. Tommy Atkins, grown in semiarid environment. The experimental design consisted of randomized blocks with five treatments, five repetitions and five plants per plot. Treatments consisted of: T1) two foliar sprays with [biostimulant $+\mathrm{KCl}$ ] + two foliar sprays with $\mathrm{K}_{2} \mathrm{SO}_{4}$; T2) No biostimulant and four foliar sprays with $\mathrm{K}_{2} \mathrm{SO}_{4}$; T3) three individual foliar sprays with biostimulant and one foliar spray with $\mathrm{K}_{2} \mathrm{SO}_{4}$; $\left.\mathrm{T} 4\right)$ two foliar sprays with biostimulant and two foliar sprays with $\mathrm{K}_{2} \mathrm{SO}_{4}$; and $\mathrm{T} 5$ ) two foliar sprays with [biostimulant $+\mathrm{K}_{2} \mathrm{SO}_{4}$ ] + one foliar spray with $\mathrm{K}_{2} \mathrm{SO}_{4}$. The variables evaluated were: i) leaf concentrations of soluble carbohydrates, starch, amino acids and proline; and ii) enzymatic activity of catalase and ascorbate peroxidase. The foliar spray with biostimulant during the branch maturation phase of mango trees grown in tropical semiarid environment alleviated plant abiotic stress. Three foliar biostimulant sprays and one $\mathrm{K}_{2} \mathrm{SO}_{4}$ spray are recommended to alleviate mango plant abiotic stress in semiarid environment.
\end{abstract}

Key words: Mangifera indica L., amino acids, enzyme activity, soluble carbohydrates, yeast extract

\section{Bioestimulante alivia o estresse abiótico da mangueira cultivada em ambiente semiárido}

RESUMO: A fase de maturação de ramos é importante no cultivo de mangueira porque precede à indução floral, quando as plantas estão sob estresse causado por elevadas temperaturas e baixa disponibilidade hídrica, que poderia ser amenizado pelo uso de bioestimulante. Assim, o presente estudo teve como objetivo utilizar um bioestimulante de plantas contendo extrato de levedura e aminoácidos na atenuação do estresse abiótico em plantas de manga, cv. Tommy Atkins, em ambiente semiárido. O delineamento experimental foi em blocos ao acaso, com cinco tratamentos, cinco repetições e cinco plantas por parcela. Os tratamentos consistiram de: T1) duas pulverizações foliares com [bioestimulante $+\mathrm{KCl}$ ] + duas pulverizações foliares com $\mathrm{K}_{2} \mathrm{SO}_{4}$; $\mathrm{T} 2$ ) sem bioestimulante e quatro pulverizações foliares com $\mathrm{K}_{2} \mathrm{SO}_{4} ; \mathrm{T} 3$ ) três pulverizações foliares individuais com bioestimulante e uma pulverização foliar com $\mathrm{K}_{2} \mathrm{SO}_{4}$; T4) duas pulverizações foliares com bioestimulante e duas pulverizações foliares com $\mathrm{K}_{2} \mathrm{SO}_{4}$; e T5) duas pulverizações foliares com [bioestimulante $+\mathrm{K}_{2} \mathrm{SO}_{4}$ ] + uma pulverização foliar com $\mathrm{K}_{2} \mathrm{SO}_{4}$. As variáveis avaliadas foram carboidratos solúveis, amido, concentração de aminoácidos e prolina, e atividade enzimática da ascobarto peroxidase e catalase. A pulverização foliar com bioestimulante durante a fase de maturação da parte aérea das mangueiras cultivadas no semiárido tropical aliviou o stress abiótico das plantas. Três pulverizações foliares de bioestimulante e uma pulverização foliar de $\mathrm{K}_{2} \mathrm{SO}_{4}$ são recomendadas para mitigar os efeitos do estresse abiótico em plantas de mangas no semiárido.

Palavras-chave: Mangifera indica L., aminoácidos, atividade enzimática, carboidratos solúveis, extrato de levedura 


\section{INTRODUCTION}

Mango is the second most exported fruit in Brazil, which is the seventh world's largest mango exporter. The São Francisco Valley, located in Northeastern Brazil, is one of the main fruit-producing regions in Brazil, responsible in 2017 for approximately $89 \%$ of the total exported Brazilian mango (FAOSTAT, 2018). As a result, mango crop in this region has been a research target in the most different areas (Lima et al., 2018; Rodrigues et al., 2018).

The São Francisco Valley is located in a tropical semiarid region with high temperatures and low air relative humidity, reaching $36.8{ }^{\circ} \mathrm{C}$ and $25.6 \%$ respectively. In addition, the agronomical practices for mango production system include water depth reduction, which is necessary to stimulate ethylene production and improve mango flowering (Ramirez \& Davenport, 2016).

The deleterious effect of high temperatures associated with low air relative humidity and water depth reduction causes high abiotic stress levels and consequently lower rates of photosynthesis, transpiration and leaf water potential (Faria et al., 2016). It demands different alleviating strategies, which can be highly advantageous for yield in subsequent growth seasons (Genú \& Pinto, 2002).

Under adverse climate conditions the use of biostimulants could be an option to alleviate abiotic stress (Oosten et al., 2017). The biochemical and molecular mechanism of action of biostimulants is still poorly understood, but plants treated with biostimulants show significant increases mainly in proline and soluble sugars (Ngoroyemoto et al., 2019), which play a key role in stress relief, providing osmotic adjustment of cells and ensuring resistance to water restriction periods (Hassanein et al., 2009).

Hence, the present study aimed to evaluate a plant biostimulant containing yeast extract and amino acids on the alleviation of abiotic stress in 'Tommy Atkins' mango growing in semiarid region.

\section{Material ANd Methods}

\section{Plant material and growing conditions}

Twenty-year-old 'Tommy Atkins' mango (Mangifera indica L.), with uniform size and vigor, were used in this study. The experiment was conducted between August and October 2017 (agricultural week 33 to 42) in an experimental orchard located in Casa Nova ( $9^{\circ} 23^{\prime} \mathrm{S}$ and $40^{\circ} 43^{\prime} \mathrm{W}$; at an altitude of 402 $\mathrm{m}$ above sea level), Bahia State, Brazil. The climate of this region is classified as BSh (Alvares et al., 2013), which corresponds to a semiarid region. During the experiment, the climatic data were collected by a meteorological station (Figure 1).

The tree's nutritional status was determined through leaf analysis before the experiment and during flowering, as can be seen in Tables 1 and 2, respectively. Leaf samples were collected in the middle part of the canopy in the last vegetative flush of branches with flowers to perform the characterization of plant nutritional status. Leaves were chemically analyzed after they were washed and rinsed with distilled water and dried at $65^{\circ} \mathrm{C}$ until reaching constant mass, following the methodology described by Bataglia et al. (1983).

The plants, spaced by $10.0 \mathrm{~m}$ between the rows and $5.0 \mathrm{~m}$ between the plants, were daily irrigated (micro-sprinkler) with two emitters per plant, for a flow of nearly $40 \mathrm{~L} \mathrm{~h}^{-1}$ each. All management practices such as pruning, control of weeds,

Table 1. Leaf nutrient concentrations of the 'Tommy Atkins' mango orchard before the experiment

\begin{tabular}{|c|c|c|c|c|c|c|c|c|}
\hline $\mathbf{N}$ & $\mathbf{P}$ & K & $\mathrm{Ca}$ & $\mathrm{Mg}$ & $\mathrm{Mn}$ & $\mathrm{Fe}$ & $\mathrm{Zn}$ & B \\
\hline \multicolumn{5}{|c|}{$\left(g_{k g} g^{-1}\right)$} & \multicolumn{4}{|c|}{$(m g ~ k g-1)$} \\
\hline 21.1 & 1.5 & 12.75 & 8.86 & 2.01 & 138.5 & 31.02 & 76.11 & 98.70 \\
\hline
\end{tabular}

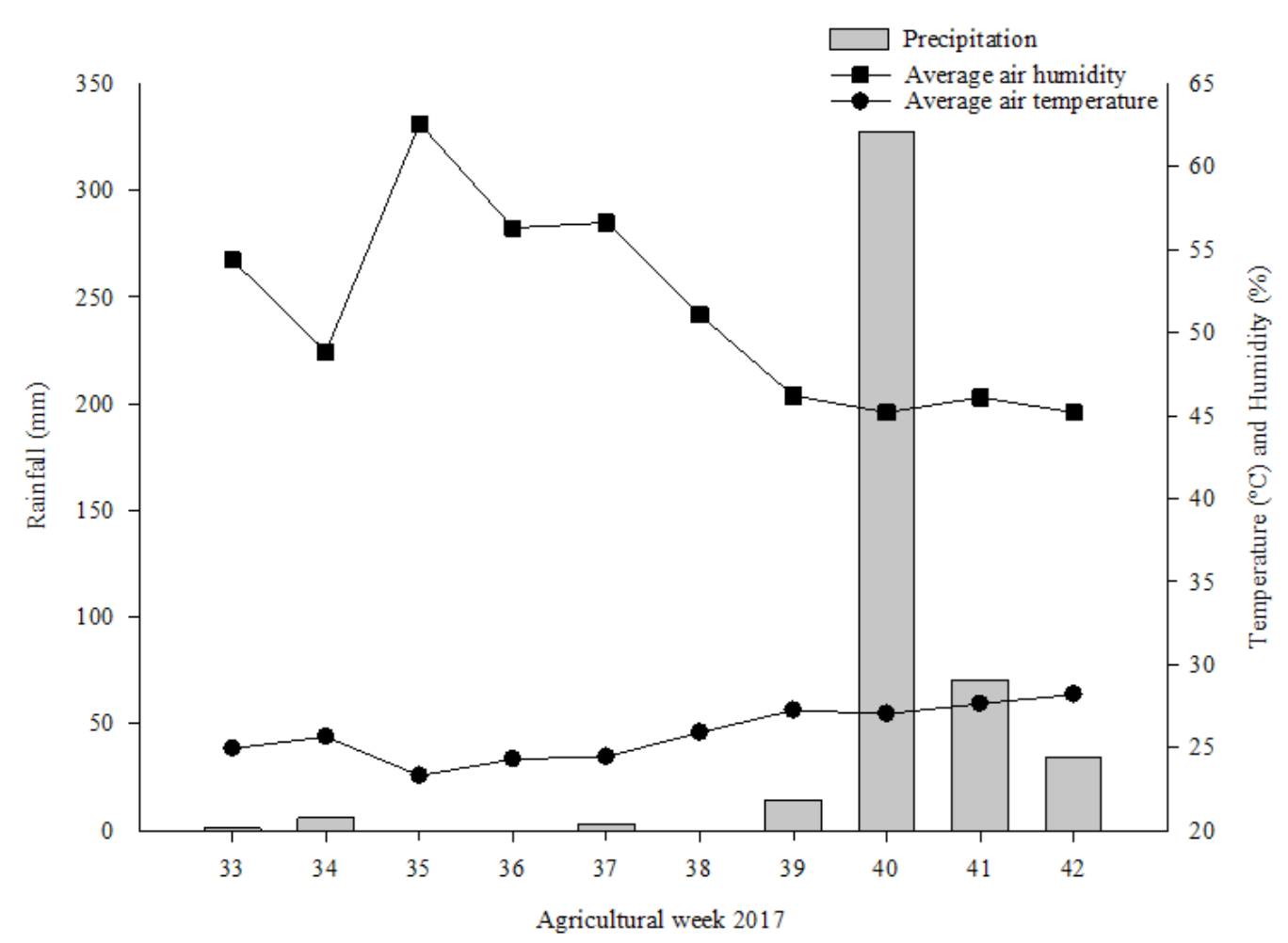

Figure 1. Mean air temperature and air relative humidity and rainfall during the execution of the experiment 
Table 2. Leaf nutrient concentrations of 'Tommy Atkins' mango at flowering for each treatment studied

\begin{tabular}{|c|c|c|c|c|c|c|c|c|c|}
\hline \multirow{2}{*}{ Treatment } & $\mathbf{N}$ & $\mathbf{P}$ & $\mathrm{K}$ & $\mathrm{Ca}$ & $\mathrm{Mg}$ & $\mathrm{Mn}$ & $\mathrm{Fe}$ & $\mathrm{Zn}$ & B \\
\hline & \multicolumn{5}{|c|}{$\left(\mathrm{g} \mathrm{kg}^{-1}\right)$} & \multicolumn{4}{|c|}{$\left.(\mathrm{mg} \mathrm{kg})^{-1}\right)$} \\
\hline T1 & 12.04 & 2.87 & 0.750 & 34.68 & 1.71 & 115.63 & 103.25 & 17.68 & 60.88 \\
\hline T2 & 12.88 & 3.54 & 0.850 & 30.50 & 1.48 & 117.02 & 109.25 & 32.18 & 58.88 \\
\hline T3 & 11.69 & 2.92 & 0.800 & 35.97 & 1.46 & 90.28 & 98.51 & 34.59 & 72.85 \\
\hline T4 & 12.04 & 3.10 & 0.725 & 35.24 & 1.49 & 102.96 & 87.85 & 54.21 & 101.80 \\
\hline T5 & 13.16 & 4.38 & 1.200 & 34.67 & 1.61 & 139.02 & 89.79 & 94.92 & 58.88 \\
\hline
\end{tabular}

$\mathrm{T} 1$ - Two foliar sprays with [biostimulant $+\mathrm{KCl}]+$ two foliar sprays with $\mathrm{K}_{2} \mathrm{SO}_{4}$; T2 - No biostimulant and four foliar sprays with $\mathrm{K}_{2} \mathrm{SO}_{4}$; $\mathrm{T}_{3}-\mathrm{Three}$ individual foliar sprays with biostimulant and one individual foliar spray with $\mathrm{K}_{2} \mathrm{SO}_{4}$; $\mathrm{T} 4$ - Two individual foliar sprays with biostimulant and two individual foliar sprays with $\mathrm{K}_{2} \mathrm{SO}_{4}$; and $\mathrm{T} 5$ - Two foliar sprays with [biostimulant $\left.+\mathrm{K}_{2} \mathrm{SO}_{4}\right]+$ one individual foliar spray with $\mathrm{K}_{2} \mathrm{SO}_{4}$

pests and diseases, application of plant growth regulators for gibberellin inhibition (28.1 mL plant ${ }^{-1}$ of Cultar $\left.{ }^{\circ}\right)$ and dormancy break (calcium nitrate and potassium nitrate at $3.0 \%)$ were performed at every seven days, following the instructions of Genú \& Pinto (2002). Nutrient management was performed through a fertigation system, according to plant demand (Genú \& Pinto, 2002; Barbosa et al., 2016). The production pruning was mechanically carried out and manual tip pruning was performed to synchronize vegetative flush events in the canopy.

The experiment followed a randomized block design with five treatments, five repetitions and five plants per plot. The treatments were defined considering the plant demands and physiological changes that occur during the branch maturation of the mango production system conducted in the São Francisco Valley, properly described by Genú \& Pinto (2002) and Cavalcante et al. (2018). This stage (branch maturation) precedes the floral induction when plants are under stress caused by high temperatures and water depth reduction that could be reduced by using plant biostimulant.

Thus, the treatments consisted of combinations of biostimulant with potassium fertilizers, as follows: T1) two foliar sprays with [biostimulant $\left(10 \mathrm{~mL}_{\text {plant }}{ }^{-1}\right)+\mathrm{KCl}\left(120 \mathrm{mg}\right.$ plant $^{-1}$, $\left.\left.60 \% \mathrm{~K}_{2} \mathrm{O}\right)\right]+$ two foliar sprays with $\mathrm{K}_{2} \mathrm{SO}_{4}\left(120 \mathrm{mg}\right.$ plant $^{-1}, 50 \%$ $\mathrm{K}_{2} \mathrm{O}$ ); T2) No biostimulant and four foliar sprays with $\mathrm{K}_{2} \mathrm{SO}_{4}$ (120 mg plant ${ }^{-1}, 50 \% \mathrm{~K}_{2} \mathrm{O}$ ); T3) three individual foliar sprays with biostimulant $\left(10 \mathrm{~mL} \mathrm{plant}^{-1}\right)$ and one individual foliar spray with $\mathrm{K}_{2} \mathrm{SO}_{4}\left(120 \mathrm{mg} \mathrm{plant}^{-1}, 50 \% \mathrm{~K}_{2} \mathrm{O}\right.$ ); $\mathrm{T} 4$ ) two individual foliar sprays with biostimulant $\left(10 \mathrm{~mL}^{2}\right.$ plant $\left.{ }^{-1}\right)$ and two individual foliar sprays with $\mathrm{K}_{2} \mathrm{SO}_{4}\left(120 \mathrm{mg} \mathrm{plant}^{-1}, 50 \% \mathrm{~K}_{2} \mathrm{O}\right)$; and $\left.\mathrm{T} 5\right)$ two foliar sprays with [biostimulant $\left(10 \mathrm{~mL}^{2}\right.$ plant $\left.^{-1}\right)+\mathrm{K}_{2} \mathrm{SO}_{4}$ (120 mg plant $\left.\left.^{-1}, 50 \% \mathrm{~K}_{2} \mathrm{O}\right)\right]+$ one individual foliar spray with $\mathrm{K}_{2} \mathrm{SO}_{4}\left(120 \mathrm{mg}\right.$ plant ${ }^{-1}, 50 \% \mathrm{~K}_{2} \mathrm{O}$ ). The doses of the products used followed the manufacturer's recommendation and the volume was standardized in $4 \mathrm{~L} \mathrm{plant}^{-1}$ for all treatments, which is enough to completely wet the canopy. For application, a Jacto Arbus sprayer was used, with an interval of 10 days between applications, and all sprays were performed in the morning.
The biostimulant used was Bulk (Alltech ${ }^{\circledR}$ ), which contains water-soluble $\mathrm{K}(12 \%$ of $\mathrm{KCl})$, organic carbon $(9.87 \%)$, amino acids (20\%), anionic surfactants and yeast extracts. Plants of T2 treatment were not sprayed with biostimulant, but four foliar sprays with $\mathrm{K}_{2} \mathrm{SO}_{4}\left(120 \mathrm{mg}\right.$ plant $\left.^{-1}, 50 \% \mathrm{~K}_{2} \mathrm{O}\right)$ were performed because during the branch maturation phase, leaf potassium sprays are necessary to equilibrate $\mathrm{N}$ :K proportion and improve the flowering uniformity in mangoes (Carneiro et al., 2017).

The treatments were applied according to the number of the days after the application of gibberellin inhibitor, paclobutrazol (PBZ) ([(2RS, 3RS)-1- (4-chlorophenyl)-4,4-dimethyl-2-(1H1,2,4-triazol-1-il) pentan-3-ol]), beginning at 45 days after PBZ (T3) and 60 days after PBZ (T1, T2, T4 and T5), based on the traditional branch maturation sprays (T2) used commercially.

All variables were recorded from the beginning of the experiment (characterization) and collected at ten days after each treatment application (sample collection 1, 2, 3 and 4), reaching five evaluation dates (Figure 2). Under the conditions of the study, the water depth reduction was $50 \%$ of crop evapotranspiration (ETc). The following variables were studied: i) concentrations of soluble carbohydrates $\left[\mathrm{mg} \mathrm{g}^{-1}\right.$ of fresh mass (FM)] and starch ( $\left.\mathrm{g} \mathrm{g}^{-1} \mathrm{FM}\right)$, quantified by following the methodology described by Dubois et al. (1956); ii) amino acid concentration ( $\mu$ mol g $\left.{ }^{-1} \mathrm{FM}\right)$ (Yemm \& Willis, 1955); iii) proline concentration ( $\left.\mu \mathrm{mol} \mathrm{g}{ }^{-1} \mathrm{FM}\right)$ (Bates et al., 1973); and iv) enzymatic activity of ascorbate peroxidase (APX) and catalase (CAT) $\left(\mu \mathrm{mol} \mathrm{H} \mathrm{O}_{2} \mathrm{~g}^{-1} \mathrm{FM} \mathrm{min}^{-1}\right)$ according to Nakano \& Asada (1981) and Beers \& Sizer (1952), respectively.

In each evaluation date, eight leaves [in each repetition, four leaves per plant (at each cardinal point) and two plants were sampled] were taken from normal shoots (last vegetative flush), from the middle part of the canopy. After being collected the leaves used for determination of soluble carbohydrates, starch, amino acids and proline concentrations were placed in paper bags, stored on ice and transported to the Plant Physiology Laboratory of the Universidade Federal do Vale do São Francisco; while the leaf materials collected for enzymatic analyses were immediately frozen in liquid nitrogen and taken to the same laboratory.

\begin{tabular}{|c|c|c|c|c|c|c|c|c|c|}
\hline Week 24 & Week 33 & Week 34 & Week 36 & Week 37 & Week 38 & Week 39 & Week 40 & Week 41 & Week 42 \\
\hline \multirow[t]{2}{*}{$\begin{array}{c}\text { PBZ } \\
\text { application }\end{array}$} & & $\begin{array}{l}\text { Characterization } \\
\text { and } \\
\text { application of }\end{array}$ & & $\begin{array}{l}\text { Application and } \\
\text { sample } \\
\text { collection of T3 }\end{array}$ & & $\begin{array}{l}\text { Application } \\
\text { and sample } \\
\text { collection of }\end{array}$ & & $\begin{array}{c}\text { Sample } \\
\text { collection of } \mathrm{T} 1 \\
\mathrm{~T} 2, \mathrm{~T} 4 \text { and } \mathrm{T} 5\end{array}$ & \\
\hline & \multicolumn{2}{|c|}{$\begin{array}{l}\text { Water depth } \\
\text { reduction }\end{array}$} & \multicolumn{2}{|c|}{$\begin{array}{l}\text { Application of } \\
\text { all treatments } \\
\text { and sample } \\
\text { collection of } \mathrm{T} 3\end{array}$} & $\begin{array}{l}\text { Application } \\
\text { and sample } \\
\text { collection of } \\
\text { all treatments }\end{array}$ & $\begin{array}{l}\mathrm{T} 1, \mathrm{~T} 2, \mathrm{~T} 4 \\
\text { and } \mathrm{T} 5\end{array}$ & $\begin{array}{l}\text { Application of T1, } \\
\text { T2, T4 and T5. } \\
\text { Sample collection } \\
\text { of all treatments }\end{array}$ & & $\begin{array}{l}\text { Increased water } \\
\text { depth and floral } \\
\text { induction }\end{array}$ \\
\hline
\end{tabular}

Figure 2. Description of the activities performed in the agricultural weeks in which the experiment was performed 
The data were subjected to the analysis of variance (ANOVA) and the treatment means were compared using the Tukey test, and correlation. All statistical analyses were performed using the SISVAR software, and averages were compared at $\mathrm{p} \leq 0.05$.

\section{Results AND Discussion}

Total leaf soluble carbohydrates concentration was significantly affected by the interaction between the biostimulant treatments and the evaluation dates studied (Figure 3A).

By evaluating the treatments within each week, it was possible to note that only week 2 showed significant difference between the treatments, with emphasis on $\mathrm{T} 3$ followed by $\mathrm{T} 2$. When the treatments are individually evaluated as a function of weeks, there is an oscillation in carbohydrate levels with significant difference for T1, T4 and T5. Based on the results, a reduction in leaf soluble carbohydrate concentrations between
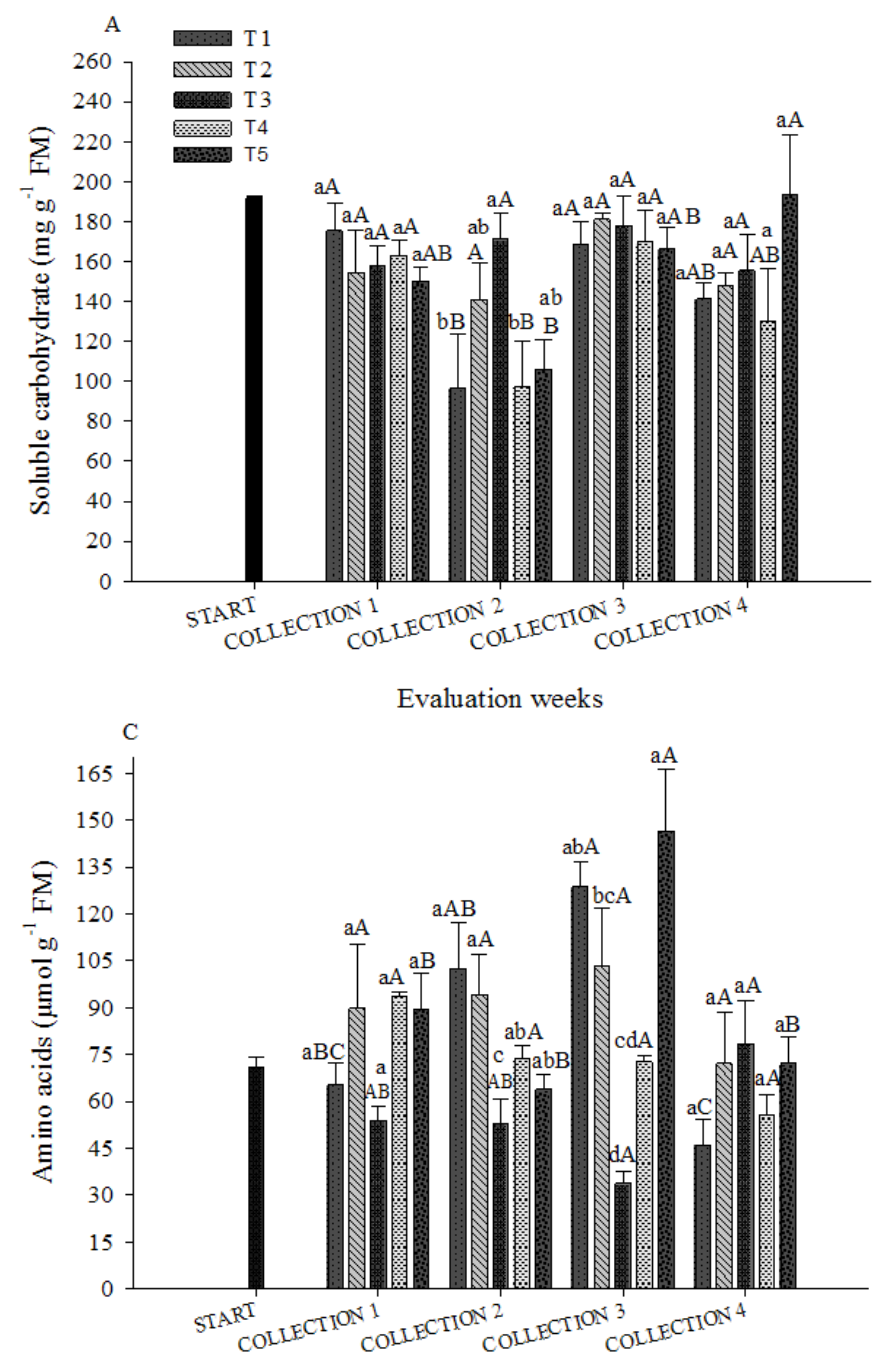

Evaluation weeks weeks 1 and 2 was observed, except for T2 and T3. However, it should be noted that, despite the absence of statistical difference, the carbohydrate values for $\mathrm{T} 3$ increased from 157.92 to $171.61 \mathrm{~g} \mathrm{~g}^{-1} \mathrm{FM}$, while those in $\mathrm{T} 2$ decreased from 154.36 to $141.06 \mathrm{~g} \mathrm{~g}^{-1} \mathrm{FM}$ (Figure 3A). It is highlighted that T3 plants were sprayed three times with biostimulant and these sprays were performed earlier [at 45 days after paclobutrazol (PBZ)] compared to the other treatments. Higher soluble carbohydrates production as a function of sprayed biostimulant has been reported in the scientific literature, as in the study of Cavalcante et al. (2018). The plant phenological phase is important to be considered for biostimulant effect, since Ramirez \& Davenport (2010) argue that for mango, the floral stimulus occurs as a function of the last vegetative flush age, so the application of the biostimulant in the initial time of the process of formation of the floral stimuli favors the longer time of action of the product in the branches and, consequently, more induction of the floral stimulus production. Considering the initial characterization of the plants (Start), the leaf soluble
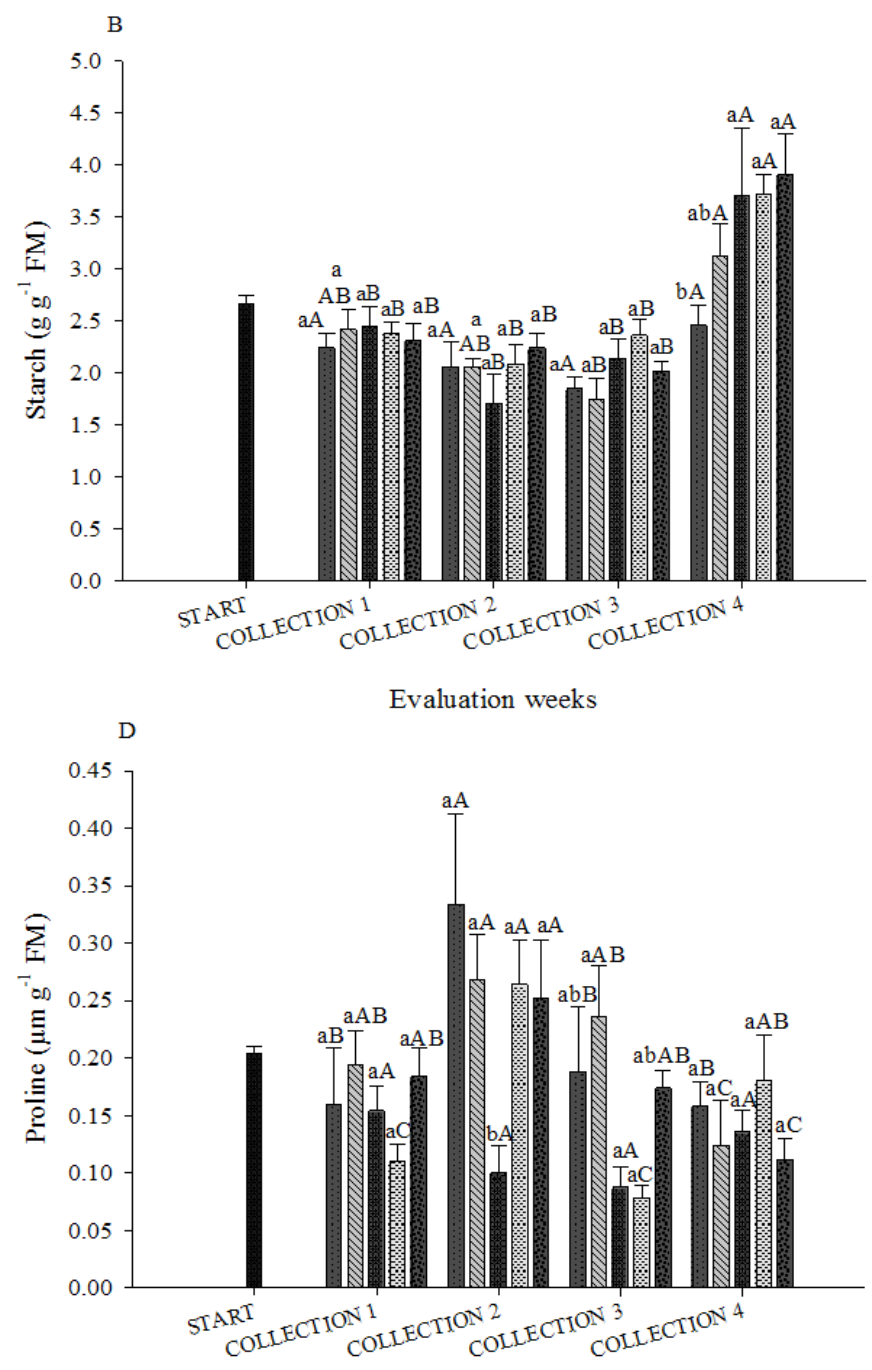

Evaluation weeks

Bars with the same capital letters do not differ on each evaluation date and bars with the same lowercase letters do not differ on the same evaluation date by Tukey's test at $\mathrm{p} \leq 0.01$. T1) Two foliar sprays with [biostimulant $+\mathrm{KCl}$ ] two foliar sprays with $\mathrm{K}_{2} \mathrm{SO}_{4}$; T2) Four foliar sprays with $\mathrm{K}_{2} \mathrm{SO}_{4}$; T3) Three individual foliar sprays with biostimulant and one individual foliar spray with $\mathrm{K}_{2} \mathrm{SO}_{4}$; T4) Two individual foliar sprays with biostimulant and two individual foliar sprays with $\mathrm{K}_{2} \mathrm{SO}_{4}$; and $\mathrm{T} 5$ ) Two foliar sprays with [biostimulant + $\left.\mathrm{K}_{2} \mathrm{SO}_{4}\right]+$ one individual foliar spray with $\mathrm{K}_{2} \mathrm{SO}_{4}$. Collection 1: week 36 (T3), week 38 (T1, T2, T4 and T5 ), collection 2: week 37 (T3), week 39 (T1, T2, T4 and T5 ), collection 3: week 38 (T3), week 40 (T1, T2, T4 and T5), collection 4: week 40 (T3), week 41 (T1, T2, T4 and T5)

Figure 3. Leaf concentrations of soluble carbohydrates (A), starch (B), amino acids (C) and proline (D) of 'Tommy Atkins' mango tree as a function of biostimulant strategy in five sample collections 
carbohydrates concentration before the treatment application was slightly higher than the concentrations obtained after the application of the treatments, a fact that may be linked to the imposition of water stress during this period. Almeida et al. (2015) reported that one of the water stress effects on plants is the lower vegetative growth, promoting the accumulation of reserves.

When branch maturation phase begins, mango plants also exhibit a 'reproductive effort', consuming assimilates for the formation of reproductive structures (Prasad et al., 2014). Thus, the tendency is that there is an oscillation of the leaf carbohydrate concentration since these solutes are synthesized but also consumed in the floral stimulus process (source/ sink relationship). The higher average value recorded in the collection 3 for all treatments (except T2 and T3) is related to the precipitation during year week number 40 (Figure 1).

According to Almeida et al. (2015), plants under water stress tend to reduce photoassimilate production and consume the accumulated amount but, on the other hand, when water is adequately supplied there is signaling for ordinary metabolism and, consequently, photoassimilate accumulation. For the last evaluation date, T5 had a higher average carbohydrate concentration, but without significant difference from the other treatments (Figure 3). In addition, the same treatment had slightly higher $\mathrm{N}$ values (Table 2), and it is therefore suggested that these results contributed to later flowering, as observed in the field. Similarly, it was also observed that T3 had a faster flowering in comparison to $\mathrm{T} 5$, which may be related to the smaller variation in leaf soluble carbohydrates recorded along the evaluation dates, suggesting a greater stability in the source-sink relationship during the branch maturation phase.

Cavalcante et al. (2018) evaluated the leaf soluble carbohydrate concentration of mango cv. Palmer as a function of different shoot maturation strategies (including a biostimulant) and observed that the carbohydrate concentrations of mango depend on shoot maturation strategy. Urban et al. (2004) evaluated leaf carbohydrate, nitrogen, and gas exchange for different branch maturation stages in mango and verified that during flowering the leaves near the floral buds had higher starch and non-structural carbohydrate average values than those near vegetative branches.

The carbohydrate metabolism guarantees energy as ATP (adenosine triphosphate), besides reducing agents and intermediary metabolism compounds that enhance $\mathrm{NO}_{3}$ assimilation, especially during flowering (Phavaphutanon \& Krisanapook, 2000). Immediately before flowering, the vegetative growth is reduced and then leaves and shoots act as sink organs, which store carbohydrates (Prasad et al., 2014); during floral induction these photoassimilates are broken for the formation of reproductive structures and then there is an increase in carbohydrate concentration (Figures 3A and B) on the last evaluation date (T5). On this date, T5 also had a higher leaf $\mathrm{P}$ content (Table 2), which implies energy storage and, consequently, late flowering, specifically for this treatment (visual contrast).

Leaf starch concentration was significantly affected by the interaction between the treatments evaluated and the evaluation dates, and it should be emphasized that only collection four showed significant difference among treatments, highlighting the superiority of T3, T4 and T5 (Figure 3B). By comparing the treatments as a function of weeks, it was observed that the leaf starch concentrations decreased with time, so a significant increase was recorded from the penultimate to the last evaluation date (full bloom), a result similar to that recorded by Urban et al. (2004).

Leaf starch concentrations decreased with time, regardless of the treatment (Figure 3B). A significant increase was recorded from the penultimate to the last evaluation date (full flowering), a result also similar to that recorded by Urban et al. (2004).

The reduction in starch concentration until the collection 3 may be caused by the sucrose conversion for the formation of the reproductive structures and other plant organs (Taiz \& Zeiger, 2013). On the other hand, for T3 and T4 (both used plant biostimulant), in the collections 2 and 3, the leaf starch concentration was enhanced, which could be associated with a flowering regulatory process and it shows a positive effect of the biostimulant. In this respect, Tanou et al. (2017) affirms that enhanced fruit tree growth and yield by biostimulants have been related to modulation in different fruit species. The average values of the present study are lower than those reported by Prasad et al. (2014), who evaluated Royal Special and Totapuri mango cultivars.

Total non-structural carbohydrates, including starch, perform a crucial function in mango development, especially for flowering (Phavaphutanon \& Krisanapook, 2000), since high carbohydrate concentrations in leaves and buds stimulate mango flowering.

As can be seen in Figure 3C, some treatments (T1, T2, and T5) increased the amino acid concentrations in the collection 3 evaluation. This result occurred probably due to an osmotic adjustment process and consequently proteolysis, i.e., proteins were degraded into simple molecules, such as amino acids. It is important to point out that on the third collection date, rain occurred (Figure 1), and it could have increased amino acid biosynthesis, due to the alleviation of stress, as also reported by Helaly et al. (2017). Indeed, Liu et al. (2011) reported that the accumulation of organic osmolytes for osmotic adjustment is believed to have great importance for physiological acclimation against water stress. Plant amino acids act on proteins biosynthesis, intermediary compounds of plant hormones, alleviation of abiotic stresses (water and heat stresses) and osmotic adjustment (Du Jardin, 2015).

Compared with those reported by Helaly et al. (2017), the amino acids values found here were similar, emphasizing that in both cases mango plants were under abiotic stress. The best responses for amino acids in the present research were obtained for $\mathrm{T} 1$ and $\mathrm{T} 5$, verified in the third collection, with means of 130 and $150 \mu \mathrm{mol} \mathrm{g}^{-1} \mathrm{FM}$, respectively, with no statistical difference between them and having the highest mean values.

Regarding the last evaluation, it was observed that all treatments reduced their concentration of free amino acids, except for the T3, which showed significant increases from the third to the fourth evaluation date. This fact can be related to the late response of the plant due to the number of sprays of the biostimulant and exposure time to PBZ (45 days). 
Regarding proline leaf concentrations, $\mathrm{T} 1, \mathrm{~T} 2, \mathrm{~T} 4$, and $\mathrm{T} 5$ showed a peak from the first to the second evaluation date and a decrease on the third date (Figure 3D); conversely, T3 showed a consecutive reduction until the penultimate sample collection, followed by a slight increase on the last date. According to Kwok \& Shetty (1998), proline enhances the total phenolic content, which prevents auxin degradation. Hence, during branch maturation it is desirable to have lower proline concentration in the shoot to induce auxin degradation, better hormone balance and, consequently, a better flowering.

Under adverse growth conditions, such as water stress, plants activate protection mechanisms such as biosynthesis of proline, since this amino acid is sensitive to environmental adversities. Proline accumulation in plants is related to the osmotic adjustment, stabilization of membranes and proteins, oxireduction equilibrium and gene expression (Ashraf et al., 2011).

The increase in proline concentration for the sample collection 2, especially for $\mathrm{T} 1$, except for $\mathrm{T} 3$, may have been caused by a mechanism of protection against stress during the branch maturation phase, since this amino acid has a high sensitivity to environmental adversities, which explains the peak for $\mathrm{T} 1$ since this treatment included $\mathrm{KCl}$ foliar spray associated with biostimulant, causing greater stress and consequently activating the defense mechanism (Ashraf et al., 2011). As chloride $\left(\mathrm{Cl}^{-}\right)$ion is supplied, it tends to accumulate at higher concentrations in vacuoles until the cell's capacity to compartmentalize $\mathrm{Cl}^{-}$is exceeded, causing osmotic stress and limited water absorption (Epstein et al., 1980; Munns, 2005). However, at the slightest sign of stress, as a defense mechanism, plants accumulate proline inside the cells so that there is osmotic adjustment with consequent maintenance of cellular integrity (Verslues \& Sharma, 2010). Lata et al. (2011) studied mango plants 'Kurukan' under salt stress $(\mathrm{NaCl})$ and found higher proline values in comparison to non-stressed plants. It is important to note that T3 (treatment with more

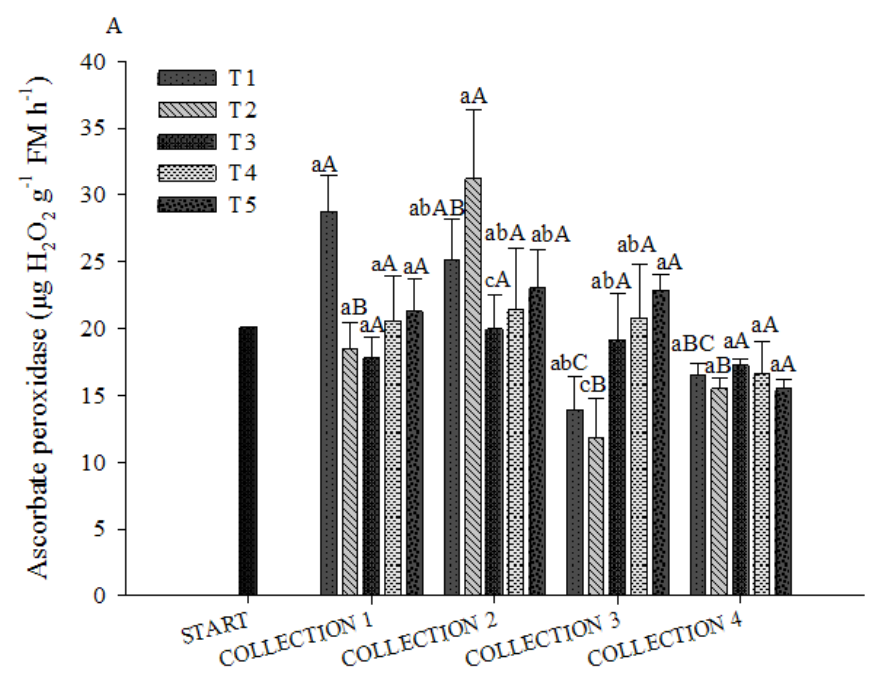

Evaluation weeks biostimulant sprays) showed a different data distribution along the evaluated dates, decreasing in the sample collections 1,2 and 3, but increasing in the last collection (Figure 3D). This sequence may be related to the plant osmotic and hormonal adjustment during the branch maturation phase. Thus, the proline data presented in Figure 3D demonstrate positive results of the biostimulant foliar spray during the mango branch maturation aiming to alleviate abiotic stress.

During the water deficit period, the production of reactive oxygen species (ROS), predominantly $\mathrm{O}_{2}^{-}$and $\mathrm{H}_{2} \mathrm{O}_{2}$, may occur. The presence of these ROS can lead to enzymes inactivation and damage important cellular components. When the ROS production exceeds the action of the antioxidative system, oxidative stress occurs, so the defense mechanisms are important to limit this stress and destroy the ROS. Among the enzymes that affect the plant protection mechanism are ascorbate peroxidase (APX) and catalase (CAT) (Munné-Bosch et al., 2013).

For APX results, a significant interaction was observed between the biostimulant treatments and the evaluation dates (Figure 4A). As can be seen in Figure 4A, for all evaluation dates there was a significant fluctuation in APX activity only for T1 and T2. For T1, it can be attributed to the effect of the sprayed salt $(\mathrm{KCl})$, causing stress and thus activating the plant's defense system. According to Srivastav et al. (2010), salinity increase causes cell membrane damage and it increases ion leakage, thus enhancing ROS. For T2 (four foliar sprays with $\mathrm{K}_{2} \mathrm{SO}_{4}$ ) an oscillatory data distribution is observed along the evaluated dates, demonstrating the instability caused by this treatment. Comparatively, T3, T4, and T5 treatments promoted stability in APX activity on all evaluation dates, suggesting that these treatments are more efficient in reducing the effects of stress, due to the function performed by the biostimulant in the oxidative process.

When comparing the treatments in the evaluation dates, there is a difference only for collections 2 and 3 . In the

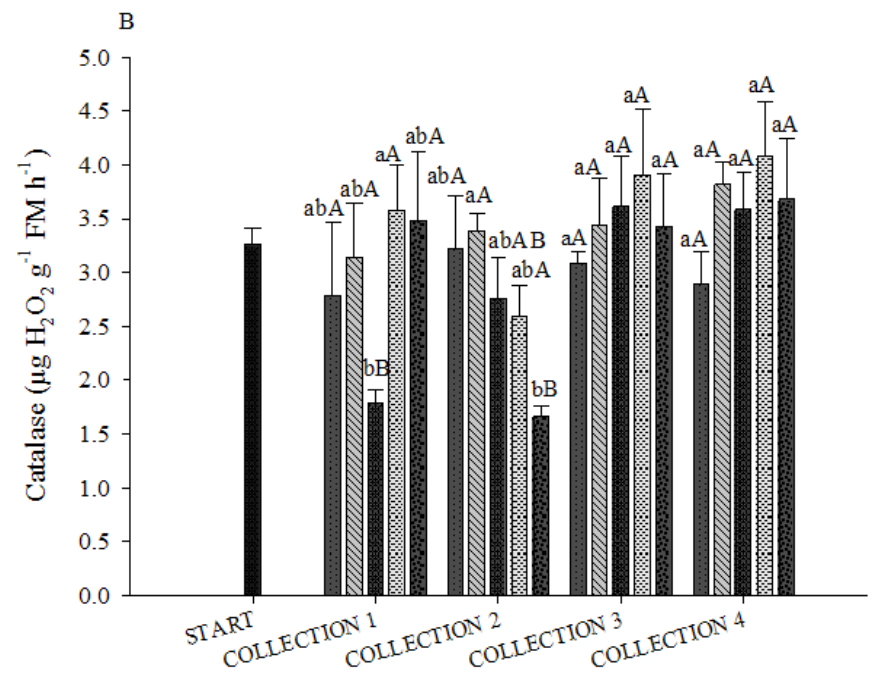

Evaluation weeks

Bars with the same uppercase letters do not differ on each evaluation date and bars with the same lowercase letters do not differ on the same evaluation date by Tukey's test at $\mathrm{p} \leq 0.01$. $\mathrm{T} 1$ - Two foliar sprays with [biostimulant $+\mathrm{KCl}$ ] + two foliar sprays with $\mathrm{K}_{2} \mathrm{SO}_{4}$; $\mathrm{T} 2$ - No biostimulant and four foliar sprays with $\mathrm{K}_{2} \mathrm{SO}_{4}$; $\mathrm{T}_{3}-\mathrm{Three}_{\mathrm{individual}}$ foliar sprays with biostimulant and one individual foliar spray with $\mathrm{K}_{2} \mathrm{SO}_{4} ; \mathrm{T} 4$ - Two individual foliar sprays with biostimulant and two individual foliar sprays with $\mathrm{K}_{2} \mathrm{SO}_{4}$; and $\mathrm{T} 5$ - Two foliar sprays with [biostimulant $\left.+\mathrm{K}_{2} \mathrm{SO}_{4}\right]+$ one individual foliar spray with $\mathrm{K}_{2} \mathrm{SO}_{4}$. Collection 1: week 36 (T3), week 38 (T1, T2, T4 and T5), collection 2: week 37 (T3), week 39 (T1, T2, T4 and T5), collection 3: week 38 (T3), week 40 (T1, T2, T4 and T5), collection 4: week 40 (T3), week 41 (T1, T2, T4 and T5)

Figure 4. Ascorbate peroxidase (A) and catalase (B) activities in leaf blades of 'Tommy Atkins' mango tree as a function of biostimulant strategy on five evaluation dates 
collection 2, the highest APX value was recorded for T2 plants (31.21 $\mathrm{g} \mathrm{H}_{2} \mathrm{O}_{2} \mathrm{~g}^{-1} \mathrm{FM} \mathrm{h}^{-1}$ ), while the lowest value was recorded for T3 (19.97 $\mu \mathrm{g} \mathrm{H}_{2} \mathrm{O}_{2} \mathrm{~g}^{-1} \mathrm{FM} \mathrm{h}^{-1}$ ) (treatment with the highest number of biostimulant applications), which demonstrates that T2 plants were under higher stress. In sample collection 3, however, rainfall was recorded, a condition that naturally attenuated the water stress to which the plants of all treatments were subjected and, therefore, there was a reduction in enzyme synthesis. The variations in values between the collections 2 and 3 were $11.26,19.41,0.78,0.6$, and $0.13 \mu \mathrm{g} \mathrm{H}_{2} \mathrm{O}_{2} \mathrm{~g}^{-1} \mathrm{FM} \mathrm{h}^{-1}$ for $\mathrm{T} 1, \mathrm{~T} 2, \mathrm{~T} 3, \mathrm{~T} 4$, and $\mathrm{T} 5$, respectively, which shows that $\mathrm{T} 1$ and $\mathrm{T} 2$ were the treatments most affected by stress alleviation. Therefore, under different conditions (sample collections 2 and 3 ), the biostimulant promoted similar responses, indicating the ability to reduce the effects of abiotic stress even under adverse conditions, as also reported by Oosten et al. (2017).

For CAT, significant interaction was recorded between the biostimulant treatments and the evaluation dates (Figure 4B). In general, catalase results were contrary to those recorded for APX, showing that treatments using salt spray $(\mathrm{KCl})$ and no biostimulant (T1 and T2) remained more stable along the evaluated dates (Figure 4B). APX and CAT enzymes are located in chloroplasts, mitochondria, cytosol and peroxisomes, and especially for CAT in glyoxysomes, effectively contributing to $\mathrm{H}_{2} \mathrm{O}_{2}$ detoxification by converting them to $\mathrm{H}_{2} \mathrm{O}$ and $\mathrm{O}_{2}$ (Shugaev et al., 2011; Saxena et al., 2011). However, APX has a higher affinity for $\mathrm{H}_{2} \mathrm{O}_{2}$ molecules, which suggests that this enzyme plays a complementary role in relation to CAT, especially in peroxisomes (Miyake \& Asada, 1996; Mhamdi et al., 2012), and thus both tend to exhibit distinct behavior, similar to that observed in Figure 4.

Helaly et al. (2017), evaluating the CAT activity in four mango cultivars (Ewaise, Hindy, Misk Ewaise and Fagri Kalan) subjected to water stress, observed average values ranging from 81.4 to $85.9 \mu \mathrm{g} \mathrm{g}^{-1} \mathrm{FM} \mathrm{h}^{-1}$

The amino acids contained in the biostimulant act as precursors and signaling substances, which can be a decisive factor for the alleviation of mango stress during the shoot maturation phase. According to Du Jardin (2015), biostimulants when applied to plants have physiological effects similar to those of phytonutrients, acting in the promotion, modification or inhibition of physiological processes.

\section{Conclusions}

1. Foliar spray with biostimulant during the branch maturation phase of 'Tommy Atkins' mango growing in tropical semiarid environment alleviates abiotic stress.

2. Three foliar sprays with biostimulant $\left(10 \mathrm{~mL}\right.$ plant $\left.^{-1}\right)$ and one with $\mathrm{K}_{2} \mathrm{SO}_{4}\left(120 \mathrm{mg}\right.$ plant $\left.^{-1}, 50 \% \mathrm{~K}_{2} \mathrm{O}\right)$, at ten-day interval, can be recommended to alleviate abiotic stress (heat and water deficit) during the branch maturation phase of 'Tommy Atkins' mango.

\section{ACKNOWLedgements}

The authors gratefully thank Alltech ${ }^{\circledast}$ for granting the support necessary to carry out the research, and to Barreiro de Santa Fé Farm (Casa Nova County, Bahia state, Brazil) for structural support necessary for the execution of the experiments.

\section{Literature Cited}

Almeida, E. I. B.; Celin, E. F.; Freire, A. G.; Lacerda, C. F.; Bezerra, M. A.; Mesquita, R. O. Ecofisiologia de mangueiras 'Tommy Atkins' submetidas a diferentes regimes hídricos e disponibilidade de luz. Revista Agro@mbiente On-line, v.9, p.251-260,2015.https://doi. org/10.18227/1982-8470ragro.v9i3.2336

Alvares, C. A.; Stape, J. L.; Sentelhas, P. C.; Moraes, G.; Leonardo, J.; Sparovek, G. Köppen's climate classification map for Brazil. Meteorologische Zeitschrift, v.22, p.711-728, 2013. https:// doi.org/10.1127/0941-2948/2013/0507

Ashraf, M.; Akram, N. A.; Alqurainy, F.; Foolad, M. R. Drought tolerance: Roles of organic osmolytes, growth regulators, and mineral nutrients. Advances in Agronomy, v.111, p.249-296, 2011. https://doi.org/10.1016/B978-0-12-387689-8.00002-3

Barbosa, L. F. S.; Cavalcante, Í. H. L.; Lima, A. M. N. Desordem fisiológica e produtividade de mangueira cv. Palmer associada à nutrição de boro. Revista Brasileira de Fruticultura, v.38, p.1-9, 2016. https://doi.org/10.1590/0100-2945-273/14

Bataglia, O. C.; Furlani, A. M. C.; Teixeira, J. P. F.; Gallo, J. R. Métodos de análise química de plantas-Boletim Técnico 78. Campinas: Instituto Agronômico, 1983, 48p.

Bates, L. S. Rapid determination of free proline for water-stress studies. Plant and Soil, v.39, p.205-207, 1973. https://doi.org/10.1007/ BF00018060

Beers, R. F.; Sizer, I. W. A spectrophotometric method for measuring the breakdown of hydrogen peroxide by catalase. Journal Biological Chemistry, v.195, p.133-140, 1952.

Carneiro, M. A.; Lima, A. M. N.; Cavalcante, Î. H. L.; Cunha, J. C.; Rodrigues, M. S.; Lessa, T. B. S. Soil salinity and yield of mango fertigated with potassium sources. Revista Brasileira de Engenharia Agrícola e Ambiental, v.21, p.310-316, 2017. https:// doi.org/10.1590/1807-1929/agriambi.v21n5p310-316

Cavalcante, Í. H. L.; dos Santos, G. N. F.; da Silva, M. A.; Martins, R. S.; Lima, A. M. N.; Modesto, P. I. R.; Alcobia, A. M.; Silva, T. R. S.; Araujo e Amariz, R. A.; Beckmann-Cavalcante, M. Z. A new approach to induce mango shoot maturation in Brazilian semiarid environment. Journal of Applied Botany and Food Quality, v.91, p.281-286, 2018.

Du Jardin, P. Plant biostimulants: Definition, concept, main categories and regulation. Scientia Horticulturae, v.196, p.3-14, 2015. https:// doi.org/10.1016/j.scienta.2015.09.021

Dubois, M.; Gilles, K. A.; Hamilton, J. K.; Rebers, P. T.; Smith, F. Colorimetric method for determination of sugars and related substances. Analytical Chemistry, v.28, p.350-356, 1956. https:// doi.org/10.1021/ac60111a017

Epstein, E.; Norlyn, J. D.; Rush, D. W.; Kingsbury, R. W.; Kelley, D. B.; Cunningham, G. A.; Wrona, A. F. Saline culture of crops: A genetic approach. Science, v.210, p.399-404, 1980. https://doi. org/10.1126/science.210.4468.399

FAOSTAT - Food and Agriculture Organization of the United Nations. Produção mundial de manga. Available on: <http://faostat3.fao. org/faostat-gateway/go/to/download/Q/QC/E > . Accessed on: Feb. 2018. 
Faria, L. N.; Donato, S. L.; Santos, M. R. D.; Castro, L. G. The effects of irrigation management on floral induction of 'Tommy Atkins' mango in Bahia semiarid. Engenharia Agrícola, v.36, p.387-398, 2016. https://doi.org/10.1590/1809-4430-Eng.Agric. v36n3p387-398/2016

Genú, P. J. C.; Pinto, A. C. Q. A cultura da mangueira. 1.ed. Brasília: Embrapa Informação Tecnológica, 2002. 452p.

Hassanein, R. A.; Bassony, F. M.; Barakat, D. M.; Khalil, R. R. Physiological effects of nicotinamide and ascorbic acid on Zea mays plant grown under salinity stress. 1- changes in growth, some relevant metabolic activities and oxidative defense systems. Research Journal of Agriculture and Biological Sciences, v.5, p.72-81, 2009.

Helaly, M. N.; El-Hoseiny, H.; El-Sheery, N. I.; Rastogi, A.; Kalaji, H. M. Regulation and physiological role of silicon in alleviating drought stress of mango. Plant Physiology and Biochemistry, v.118, p.31-44, 2017. https://doi.org/10.1016/j.plaphy.2017.05.021

Kwok, D.; Shetty, K. Effects of proline and proline analogs on total phenolic and rosmarinic acid levels in shoot clones of thyme (Thymus vulgaris L.). Journal of Food Biochemistry, v.22, p.37-51, 1998. https://doi.org/10.1111/j.1745-4514.1998.tb00229.x

Lata, K.; Srivastav, M.; Dubey, A. K.; Singh, A. K.; Sairam, R. K. Effect of polyamines on seedlings of two mango (Mangifera indica L.) rootstocks under salt stress. Indian Journal of Plant Physiology, v.16, p.258-267, 2011.

Lima, A.; Cardoso, J.; Cunha, T.; Rodrigues, M.; Hernani, L.; Cunha, J.; Amaral, A.; Neto, M. Changing in chemical and physical attributes of a sandy soil under irrigated mango cultivation in semiarid region. Comunicata Scientiae, v.8, p.404-413, 2018. https://doi. org/10.14295/cs.v8i3.2544

Liu, H.; Yang, W.; Liu, D.; Han, Y.; Zhang, A.; Li, S. Ectopic expression of a grapevine transcription factor VvWRKY11 contributes to osmotic stress tolerance in Arabidopsis. Molecular Biology Reports, v.38, p.417-427, 2011. https://doi.org/10.1007/s11033-010-0124-0

Mhamdi, A.; Noctor, G.; Baker, A. Plant catalases: Peroxisomal redox guardians. Archives of Biochemistry and Biophysics, v.525, p.181194, 2012. https://doi.org/10.1016/j.abb.2012.04.015

Miyake, C.; Asada, K. Inactivation mechanism of ascorbate peroxidase at low concentrations of ascorbate; hydrogen peroxide decomposes compound I of ascorbate peroxidase. Plant and Cell Physiology, v.37, p.423-430, 1996. https://doi.org/10.1093/ oxfordjournals.pcp.a028963

Munné-Bosch, S.; Queval, G; Foyer, C. H. The impact of global change factors on redox signaling underpinning stress tolerance. Plant Physiology, v.161, p.5-19, 2013. https://doi.org/10.1104/ pp.112.205690

Munns, R. Genes and salt tolerance: Bringing them together. New Phytologist. v.167, p.645-663, 2005. https://doi.org/10.1111/ j.1469-8137.2005.01487.x

Nakano, Y.; Asada, K. Hydrogen peroxide is scavenged by ascorbatespecific peroxidase in spinach chloroplasts. Plant and Cell Physiology, v.22, p.867-880, 1981.

Ngoroyemoto, N.; Gupta, S.; Kulkarni, M. G.; Finnie, J. F.; Van Staden, J. Effect of organic biostimulants on the growth and biochemical composition of Amaranthus hybridus L. South African Journal of Botany, v.124, p.87-93, 2019. https://doi.org/10.1016/j.sajb.2019.03.040
Oosten, M. J. van; Pepe, O.; Pascale, S. de; Silletti, S.; Maggio, A. The role of biostimulants and bioeffectors as alleviators of abiotic stress in crop plants. Chemical and Biological Technologies in Agriculture, v.4-5, p.1-12, 2017. https://doi.org/10.1186/s40538017-0089-5

Phavaphutanon, L.; Krisanapook, K. Changes of total non-structural carbohydrates within shoots of 'Nam dok mai' mango after paclobutrazol application. Acta Horticulture, v.509, p.559-564, 2000. https://doi.org/10.17660/ActaHortic.2000.509.63

Prasad, S. S.; Reddy, Y. T. N.; Upreti, K. K.; Rajeshwara, A. N. Studies on changes in carbohydrate metabolism in regular bearing and "off" season bearing cultivars of mango (Mangifera indica L.) during flowering. International Journal of Fruit Science, v.14, p.437-459, 2014. https://doi.org/10.1080/15538362.2014.897891

Ramirez, F.; Davenport, T. L. Mango (Mangifera indica L.) flowering physiology. Scientia Horticulturae, v.126, p.65-72, 2010. https:// doi.org/10.1016/j.scienta.2010.06.024

Ramirez, F.; Davenport, T. L. Mango (Mangifera indica L.) pollination: A review. Scientia Horticulturae, v.203, p.158-168, 2016. https:// doi.org/10.1016/j.scienta.2016.03.011

Rodrigues, M. S.; Alves, D.; Souza, V. C.; Melo, A. C.; Lima, A. M. Spatial interpolation techniques for site-specific irrigation management in a mango orchard. Comunicata Scientiae, v.9, p.93-101, 2018. https://doi.org/10.14295/cs.v9i1.2645

Saxena, S. C.; Joshi, P. K.; Grimm, B.; Arora, S. Alleviation of ultraviolet-C-induced oxidative damage through overexpression of cytosolic ascorbate peroxidase. Biologia, v.66, p.1052-1059, 2011. https://doi.org/10.2478/s11756-011-0120-4

Shugaev, A. G.; Lashtabega, D. A.; Shugaeva, N. A.; Vyskrebentseva, E. I. Activities of antioxidant enzymes in mitochondria of growing and dormant sugar beet roots. Russian Journal of Plant Physiology, v.58, p.387-393, 2011. https://doi.org/10.1134/ S1021443711020208

Srivastav, M.; Kishor, A.; Dahuja, A.; Sharma, R.R. Effect of paclobutrazol and salinity on ion leakage, proline content and activities of antioxidant enzymes in mango (Mangifera indica L.). Scientia Horticulturae, v.125, p.785-788, 2010. https://doi. org/10.1016/j.scienta.2010.05.023

Taiz, L.; Ziger, E. Fisiologia Vegetal. 5.ed. Porto Alegre: Artmed, 2013. 586p.

Tanou, G.; Ziogas, V.; Molassiotis, A. Foliar nutrition, biostimulants and prime-like dynamics in fruit tree physiology: New insights on an old topic. Frontiers in Plant Science, v.8, p.1-9, 2017. https:// doi.org/10.3389/fpls.2017.00075

Urban, L.; Lu, P.; Thibaud, R. Inhibitory effect of flowering and early fruit growth on leaf photosynthesis in mango. Tree Physiology, v.24, p.387-399, 2004. https://doi.org/10.1093/treephys/24.4.387

Verslues, P. E.; Sharma, S. Proline metabolism and its implications for plant-environment interaction. The Arabidopsis Book/ American Society of Plant Biologists, v.8, p.1-23, 2010. https:// doi.org/10.1199/tab.0140

Yemm, E. W.; Willis, A. J. The estimation of carbohydrates in plant extracts by anthrone. Biochemical Journal, v.57, p.508-514, 1955. https://doi.org/10.1042/bj0570508 